\title{
TOLERANCE AS A VALUE OF A FUTURE HIGHER EDUCATION TEACHER
}

\begin{abstract}
Approaches to the interpretation of the term "tolerance" are revealed. The preparation of the future teacher for the formation of tolerance as an important component of the system of his professional training is outlined. The organizational and pedagogical conditions of activity of the institution of higher education which provide preparation of future teachers for formation of tolerance in them are defined. Keywords: formation, tolerance, pedagogical condition.
\end{abstract}

Introduction. The system of higher education, which prepares the future teacher for professional activity in the multicultural world, has a decisive role in solving the problems of tolerance formation. It is the teacher who has the leading mission in building the educational process in a way that would emphasize the importance of tolerant relations in society. These considerations are especially relevant for the Ukrainian state, which, after gaining independence, remains multinational in its composition and with different religious denominations.

The importance of interethnic tolerance is growing, because it is this phenomenon that ensures success in the process of solving the problem of consolidation of the Ukrainian nation, the formation of a new type of civil society. Tolerance is a guarantee of stability, unity of society, an indicator of readiness for peaceful coexistence with the world community and community.

The need to increase the level of tolerance at the state and interstate levels is due to the processes of globalization of social development taking place in the economic and political activities of the world community, which have the following features: creation of a common regional and world economic, information, communication space; world communities (European Union, World Trade Organization); the transition of mankind to scientific and information technologies, deepening the development of social relations.

At the same time, the problem of forming tolerance in future teachers of higher education remains poorly studied. However, there are contradictions between: 1) the urgency of the problem of educating the tolerance of the individual in modern Ukraine and its insufficient research in pedagogical science; 2) socially conditioned need to prepare future teachers for the formation of tolerance and insufficient development of ways to solve this problem; 3 ) the potential of the process of professional training of future teachers to form tolerance in students and the unfounded pedagogical conditions of its implementation. The exceptional importance of the researched problem is strengthened by the Declaration of Principles of Tolerance, approved by the resolution of the General Conference of UNESCO, by a number of state documents.

The purpose of the article - to justify the essence of tolerance as a human virtue and value of the future teacher of high school.

Analysis of recent researches and publications. The urgency of forming interethnic tolerance is growing in connection with the discovery of such a negative phenomenon in society as intolerance. Manifestations of intolerant behavior are observed in xenophobia. Discrimination. The problem of terror is gaining new global significance.

In pedagogical science, tolerance is studied through the prism of multicultural education (I. Bekh, O. Hryva, O. Sukhomlynska); cultures of interethnic communication (T. Atroshchenko, O. Gubenko, I. Palko); pedagogy of peace (O. Bezkorovaina, M. Kabatchenko, O. Kopitsa). G. Volyk,
V. Kuzmenko, O. Orlovska study the problems of preparing the future teacher for the education of students' tolerance.

A number of modern pedagogical researches are directed on education of tolerance at students of institutions of higher education in the course of studying of a foreign language T. Belous; features of education of tolerance at lyceum students of France; possibilities of application of French pedagogical experience in the domestic system of education O. Matienko; formation of tolerance in the field of student relations in the multicultural environment of higher education Ya. Dovgopolova, O. Stolyarenko; education of tolerance as a professionally significant quality of personality of a teacher of a modern national school - Yu. Todortsev. Their research is aimed at identifying, substantiating and experimentally testing pedagogical conditions that effectively influence the formation of tolerant personality traits, the characterization of interpersonal tolerant relationships, behavioral response, a system of tolerant attitudes, and is a significant contribution to the development of domestic science.

The purpose of the article is to reveal the approaches to the interpretation of the term "tolerance" and to determine the organizational and pedagogical conditions of higher education institutions that provide training for future teachers to form tolerance in them.

According to the purpose the following tasks of research are defined: 1) to find out essential characteristics of tolerance as professional quality of the person on the basis of the analysis of philosophical, social-psychological, pedagogical literature and content of the Internet; 2) to determine and substantiate the organizational and pedagogical conditions that ensure the effective formation of tolerance in future teachers of free economic education.

Presentation of the main positions. In a multicultural society, the teacher should be an initiator in the active support of such a dialogue of cultures, through which students would have the opportunity to learn the essence of themselves and others through comparison and interaction with them, acquire skills of empathy, practical cooperation between different ethnic groups. Accordingly, the importance of tolerance is growing, which is a defining and necessary condition for dialogue.

No less important is the role of the teacher - to lead the ideas of the basic principle of political strategy - the peaceful coexistence of states, countries and peoples, the rejection of any forceful methods of resolving interethnic and interfaith conflicts. With the expansion and deepening of human communication, there is a growing need to form a person who can build these relationships on the principles of tolerance: respect, acceptance and understanding of the world's cultures, forms of self-expression and ways of human individuality, harmony in diversity.

Given the development of the world information space, the teacher must form in the younger generation the ability to live and work in fundamentally new conditions, based on the principles of tolerance, mutual understanding, 
cooperation. In this regard, the preparation of the future teacher to cultivate tolerance of students is defined as a socio-pedagogical problem.

Theoretical and methodological analysis of tolerance shows that among the various approaches to the study of this phenomenon S. llyinska outlines the axiological approach and interprets tolerance as "value in itself" (for G. Marcuse - "goal in itself", for GI Nicholson - "good in myself") or as one of the values of liberal democracy; idealistic, whose supporters see in tolerance a certain ideal to which society must strive; ontological-historical, which interprets tolerance as a certain way of coexistence of groups in history; conflict - as a struggle, of course, within certain limits, which can not be defined a priori, because they are determined by the practice of struggle.

Ukrainian scientist $\mathrm{O}$. Shayuk expanded the classification of methodological approaches and singled out the epistemologic - justifies the imperfection of their own knowledge and the possibility of knowing the truth and other knowledge; xenological - based on the assertion of a different attitude to another as a stranger; existential-humanistic studies tolerance as a way of life in the context of a person's fulfillment of his human mission; socio-cultural - realizes tolerance as the intention of universal needs and interests and appears as a fundamental form of any effective social interaction; V. Stepin - enables the achievement of higher levels of tolerance in the life of various subjects and communities (individual, group, ethnic group, nation, society, humanity) by establishing full-fledged, especially in the sociopsychological format, interactions and relationships; denies aggression and intolerance in all its forms.

The most complete concept of tolerance is revealed in the Declaration of Principles of Tolerance. "Tolerance means respect, perception and understanding of the rich diversity of cultures of our world, forms of self-expression and selfexpression of the human person, tolerance is unity in diversity. It is not only a moral obligation, but also a political and legal one. Tolerance is what makes peace possible, facilitates the transition from a culture of war to a culture of peace" (Declaration of the Principles of Tolerance).

Most scholars, including I. Zhdanov and S. Shchekoldin, define different types of tolerance: political, racial, national, religious, educational, gender, physiological, and so on. According to Ukrainian scholars I. Kyrychenko and N. Panina, national tolerance can be interpreted as the potential for maintaining peace and tranquility in the country, and as an indicator: the degree of readiness of the mass consciousness to openness and cooperation with the world community based on universally recognized democratic principles.

Ukrainian researcher of interethnic tolerance in the political process of Ukraine I. Kushnirenko distinguishes between "tolerance" and "interethnic tolerance", where tolerance is objectively necessary as a mandatory regulatory tool, as a multifaceted current "organizing force" in the development of society and social consciousness, which gives the ability to interpret it as a structural component in the organization of society and the achievement of political progress. International tolerance is a specific feature of the national character, which is manifested in tolerance and evaluation of the national "they", equivalent to "we". In essence, interethnic tolerance is the ideological basis of ethnic diversity and at the same time a policy of compromise, consent and unity. Therefore, interethnic tolerance is one of the principles of state national policy, characterized by cooperation of different nationalities. At the present stage of development of our state, interethnic tolerance, namely its formation, is of great importance for Ukraine as a polyethnic state, which includes different national minorities with their ethnic, cultural and linguistic identity, and is the main psychological and pedagogical problem.

The preparation of the future teacher for the formation of tolerance of students should be interpreted as an important component of the system of his professional training. The basis in this direction is fundamental research on higher school pedagogy (A. Aleksyuk, I. Bekh, I. Zyazyun, A. Kuzminsky, O. Infantry), theories and practices of professional training of future teachers (O. Akimova, G. Ball, R Gurevich, I. Zyazyun, N. Nichkalo, 3. Courland, G. Tarasenko); concepts of training future teachers on the basis of personality-oriented education (I. Bekh, O. Bondarevskaya, I. Pidlasy), competence approach to professional training of future teachers (I. Karpyuk, O. Ovcharuk), activity approach (O. Leontiev, V. Davydov), culturological approach (V. Bibler, O. Verbytsky, V. Slastyonin).

It should be noted that the components of the process of preparing future teachers for the education of interethnic tolerance are: motivational, orientation, activity, personal.

Features of training future teachers to work in a multicultural environment are: knowledge of cultural diversity; professional orientation on education of interethnic tolerance of students, mastering of methods of influence in a situation of cultural interaction; the presence of "own interethnic identity", a tolerant attitude to cultural and ethnic diversity, which is realized in future professional activities.

The readiness of the future teacher to form their own tolerance and students should be defined as its integrative characteristics, which implies the presence of professional orientation in the specified direction of education, ability to organize activities, the presence of personal traits necessary to build tolerant relationships.

Studying the state of readiness of future teachers to form in them tolerance and education of students 'tolerance by motivational criterion, the following indicators are distinguished: motives for acquiring knowledge and skills on the problems of preparing future teachers to educate students' interethnic tolerance; the focus of the future teacher on the education of interethnic tolerance in students (the presence of interest, desire, aspiration); the presence of the aspirations of the future teacher to professional selfimprovement, to obtain a positive result in the education of interethnic tolerance in students; orientation of the future teacher on development of tolerant relations in collective and on prevention of difficulties in work on education of interethnic tolerance of pupils. The presence of motives is characterized by stability, intensity, expressiveness.

In general, tolerance (Latin tolerans (tolerantis) - patient) is considered as: 1) personal quality, a sign of a humane person or 2) one of the principles of humanistic education. Tolerance can be understood as a partnership in communication, as a subject-subject interaction (I. Bekh, A. Petrovsky); as the formation of a culture of dialogue (M. Bakhtin, V. Bibler); as the formation of attitudes of tolerant consciousness (O. Asmolov, G. Soldatova, L. Shaigerova); as the ability of an individual without denial and opposition to perceive other people's thoughts, lifestyle, behavior and other features, which in sum is the basis for the rejection of aggression ( $S$. Bondyreva, D. Kolesov) [Entsyklopediia osvity, 2008].

The opposite of tolerance is intolerance. Tolerance must be distinguished from passive voluntariness (after all, such passive acceptance does not express a positive value of judgment, and does not form the opposite of deviation).

Due to the multifaceted nature of the phenomenon of "tolerance" in the theory of modern scientific knowledge there 
are different approaches to understanding this phenomenon. The philosophical aspect offers the consideration of tolerance as a willingness to constantly and with dignity to perceive a person, thing or event, as patience, tolerance, endurance, reconciliation. The political context focuses on respect for the freedom of another person, his views, thoughts, behavior. Sociology interprets tolerance as mercy, delicacy, commitment to another, etc. [Khomyakov, 2003].

In the general pedagogical context, tolerance is interpreted as a willingness to accept others as they are and interact with them on the basis of consent and understanding [Bekh, 2001; Bekh, 2008].

Tolerance is a feature of the behavior and lifestyle of others; tolerance of other people's way of life, behavior, customs, feelings, ideas, beliefs is a condition for the stability and unity of societies, especially those that are not homogeneous in religious, ethnic or other social dimensions [Artimonova, 2008].

The concept of tolerance is fundamentally a moral concept that has become a political and legal concept. Tolerance is a human virtue, and in the sense of morality means tolerance of differences among people, the ability to live without disturbing others, the ability to have rights and freedoms without violating the rights and freedoms of others [Etyka, 2002].

According to the philosophical encyclopedic dictionary, "tolerance" is a term used to describe a friendly or, at least, restrained attitude to individual and group differences (religious, ethnic, cultural, civilizational). The worldview basis of tolerance is the appreciation of diversity - natural, individual, cultural [Filosofs'kyy entsyklopedychnyy..., 2002].

Tolerance is an understanding (awareness) of the needs and problems of another person or group of people, and therefore - tolerance for these needs and problems. And understanding (awareness) is not possible without knowledge.

An example of the harmfulness of misinterpreting the concept of "tolerance" is the imposition of stereotyped patterns of behavior. When a child at school is constantly told that a certain category of people should be "tolerant", but do not explain why (or say "so accepted", "culture of behavior", etc.). Faced with real-life episodes where "tolerance / tolerance" needs to be demonstrated, a person with such attitudes becomes understaffed and acts according to his or her logic of behavior, rather than obscure patterns imposed by someone [Sukhomlyns'ka, 1997].

The best way to achieve tolerance for a certain category of people is to give society the most accessible and understandable information about how a person lives, who is different from others, what his needs are, what problems he has, what opportunities he has, what can be useful for society. Because for each person the most valuable and important knowledge is that which he reached with his own mind, comparing and analyzing the information obtained. Tolerance implies respect for society and each individual member [Zhelanova, 2008].

Pedagogical conditions for creating tolerance in education are: 1) the formation of a tolerant space, an environment characterized by the unity of all subjects of the educational process and forms of organization of their relations, which, on the one hand, are the main components of pedagogical ethics, and on the other - the basis, model moral education of students; 2) the culture of communication in dialogue, as mutual understanding, mutual respect, compassion and empathy, a sense of partnership; 3) synergetic thinking, which allows you to perceive a wide range of personal qualities, individual and ethnic manifestations of man; 4) personality-oriented approach in the educational process, the basis of which is the subject-subject relationship in the system "educatorpupil" [Zalesova, 2015].

It is worth focusing on the principles of tolerance in education: trusting cooperation - the establishment in the educational institution of relations of mutual understanding and mutual demands between the administration, teachers, on the one hand, and students, on the other; ecology of relationships - providing a favorable socio-psychological climate in the educational institution as a basis for the formation of a tolerant environment; formation of selfesteem, self-esteem, respect for the environment, peoples, regardless of their social affiliation, nationality, race, culture, religion; synergetism, which ensures the development of personality, is its source and driving force; creativity, which ensures the implementation of variable approaches to the establishment of tolerant relations and analysis of the situation of interaction.

It should be noted that a creative approach to the use of the principle of tolerance is the key to the effectiveness of the whole process of education and creates favorable conditions for further adaptation of the individual in other areas of social relations. Tolerance in education involves: the development of observation skills, the ability to self-analysis, self-knowledge; formation of skills of positive internal dialogue with oneself; development of the ability to get to know other people, analysis of the situation, circumstances in the family, class, group, team; implementation of self-assessment correction; formation of empathy and reflection, which promote tolerant communication; development of emotional stability in difficult life situations; mastering the methods of self-regulation and response to intolerance [Kalashnikova, 2014].

The basis of tolerance in education is the recognition of the rights of others to life, death, freedom and dignity; benevolent awareness of the presence in their social environment of representatives of other cultures, recognition of the positive aspects of diversity; ability to appreciate various manifestations of people; the ability to see common, mutually beneficial goals and interests for different people, groups and to achieve them; recognition of the interdependence of human existence [Solovei, Kudina \& Spitsyn, 2013].

The activity of the teacher from the standpoint of tolerance has three aspects: the personality of the educator, which is characterized by tolerant qualities; manifestation of tolerance in professional activity; implementation of the principles of tolerance in pedagogical communication. A tolerant educator realizes that he is perceived as a role model, masters and uses appropriate skills to develop dialogue and peaceful conflict resolution; encourages creative approaches to problem solving; provides conditions for joint constructive activity of participants of educational process and for personal achievements, does not support aggressive behavior or the sharpened rivalry; promotes the involvement of students and parents in decision-making and development of joint activities; teaches to think critically and appreciate the positions of others; clearly formulates its own position on controversial issues; appreciates cultural diversity and creates conditions for the recognition of cultural differences and their manifestations in life [Zalesova, 2015].

Ways to implement tolerance in education are developed in the pedagogy of tolerance - "pedagogy of cooperation", "pedagogy of success", "pedagogy of dialogue", "pedagogy of nonviolence" (Sh. Amonashvili, I. Volkov, E. Ilyin, S. Lysenkova, V. Sukhomlinsky and etc.), according to which the achievement of positive results in the upbringing of children is possible provided that their interests are taken into account, giving them the right to free choice, sensitive attitude to them and adequate acceptance of all their 
positive and negative features. The main positions of these pedagogical systems are the manifestation of interest in the child's life, his experiences; communication with her as an adult, who is expected to have mutual trust, respect, understanding; taking into account the internal motivation of her behavior; establishing sincere and trusting relationships with the child, creating an atmosphere of cooperation, co-creation.

Consider the organizational and pedagogical conditions that provide training for future teachers to form tolerance in them and ensure the effectiveness of their preparation for the education of tolerance in students. The first condition is the optimal combination of theoretical, methodological, practical, components of training future teachers to form tolerance of students. The problem of the relationship between theory and practice is closely related to the study of the competence approach to the training of future teachers.

According to the position of A. Verbytsky, to form a holistic structure of future professional activity of a specialist it is necessary to organize such training that provides the transition, transformation of one type of activity (cognitive) into another (professional) with a corresponding change of needs, motives, goals, actions, means and results. Contextual learning is the best way to ensure the unity of theoretical and practical training of future teachers for the formation of tolerance.

The second important condition for the formation of tolerance is to take into account the peculiarities of personality-oriented learning in the training of future teachers (I. Bekh, O. Bondarevskaya, I. Pidlasy, S. Podmazin) and the study of tolerance, it can be seen that the principles of personality-oriented learning personality.

Personality-oriented learning influences the values of tolerant culture of each member of society, which are not knowledge, but the meanings of tolerance, tolerant states, not skills, but individual characteristics, independent learning activities and life experiences aimed at tolerant learning, not a pedagogical requirement., and pedagogical support and care, cooperation and dialogue, not the amount of information learned, but the holistic development and personal growth of the future teacher.

The third condition for the formation of tolerance is the activation of cognitive activity of students by creating and solving situations of multicultural content. Creating and solving situations of multicultural content stimulate interest in the problem, provide an opportunity to deeply study trends in its development, develop and consolidate the experience of social, professional behavior of the future teacher, put him in a situation of choice, resulting in testing and formation of tolerance, ability to pose in place of another person, to predict situations for her, to anticipate the most probable decisions, to coordinate their own actions with them.

The condition for the formation of tolerance is also the use of interactive learning technologies in the preparation of future teachers for the formation of tolerance of students. This condition will ensure a positive interdependence between the participants of the interaction; reflection - the process of reflection on values: equality, objectivity, respect, justice, etc .; interaction on equal terms, which will provide students with the opportunity to discuss and reflect, recognizing others as equals in terms of diversity [Tsinnosti osvity..., 1997].

It should be noted that the teacher must be a tolerant, competitive specialist. It is necessary to allocate directions of socially-civil and professionally-personally significant qualities of the teacher:

1) educational and qualification (qualities of a teacher as a specialist that meet certain educational standards regarding the professional and personal readiness of a graduate of a higher educational institution to perform their duties);

2) social and personal (socially significant qualities of a teacher as a representative of a certain society and a translator of its cultural and national heritage);

3 ) creative (creative potential and creative qualities of the teacher), technological (technology of their formation);

4) developmental (mechanisms of development of professional and pedagogical qualities of the teacher), mental activity (main aspects of pedagogical thinking of the teacher), which realize the corresponding qualities in their dialectical unity and correspond to the components of personality.

Thus, the teacher's personality is defined as the generalization and practical embodiment of all "human" spiritual and practical, that affirms the teacher in society as a subject of progressive progress of mankind, a fully developed personality of a professional patriot, able to actively participate in social and professional processes. transformations, capable of reflection and endowed with a sense of self-worth, pedagogical optimism, capable of perceiving the self-worth of another person, to spiritual, moral and aesthetic improvement, the establishment of socially progressive priorities, scientific knowledge, universal moral values, intuition, self-conception, emotion, openness to innovation, self-realization.

The axiological imperative for the development of pedagogical education in Ukraine is the training of a new generation of teachers capable of successful professional activity in the conditions of introduction of the humanistic educational paradigm.

During the years of Ukraine's independence, a number of normative acts aimed at achieving this strategic goal were adopted, namely: Laws of Ukraine "On Education " (1991), "On General Secondary Education" (1999), "On Higher Education (2014)", "On Innovative Activity" (2002), "On Urgent Measures to Ensure the Functioning and Development of Education in Ukraine" (2012), Regulations on General Education Institutions (2010), Regulations on the Procedure for Implementing Innovative Educational Activities (2012), etc.

The priorities of the development of the domestic higher education system specified in the state documents determine its focus on integration into the European educational space, as well as promoting sustainable development of society by preparing "competitive human capital and creating conditions for lifelong learning" (Law of Ukraine "On Higher Education", 2014).

Modern education, which develops in the conditions of market relations, requires from the teacher a high level of compliance with the requirements of the subjects of pedagogical interaction (students, their parents, colleagues) and society (laws, regulations, instructions, etc.). This necessitates the formation of the teacher's tolerance and competitiveness as qualities that allow to be professionally in demand in society in general and in a particular teaching staff in particular.

Conclusions. The essential characteristics of tolerance as a professional quality of personality are clarified on the basis of the analysis of philosophical, socio-psychological, pedagogical literature and Internet content. The origins of the essence of the concept of this phenomenon are the consideration of such definitions as "tolerance", "nationality". Tolerance is objectively necessary as a mandatory regulatory tool, as a multifaceted "organizational force" in the development of society and social consciousness, which allows to interpret it as a structural component in the organization of society. International 
tolerance is defined as a specific feature of the national character, which is manifested in tolerance and evaluation of the national "they", equivalent to "we". In essence, interethnic tolerance is the ideological basis of ethnic diversity and at the same time a policy of compromise, consent and unity. The criteria for the readiness of future teachers to cultivate tolerance are the following components - motivational, orientation, activity and personal.

Organizational and pedagogical conditions of organizational and pedagogical conditions of higher education institution are determined, which provide training of future teachers for the formation of tolerance, ensure effectiveness in preparing future teachers for the formation of tolerance in students: the optimal combination of theoretical, methodological and practical components of future teachers. tolerance and tolerance of students; taking into account the peculiarities of personality-oriented learning in the preparation of future teachers for the formation of tolerance of students; activation of students' cognitive activity by creating situations; application of interactive learning technologies.

The implementation of these conditions is based on a set of interrelated approaches (positive motivational environment, safe environment, cognitive experience, empathy, practical experience); based on the principles of dialogicity, unity in diversity, systematicity, consistency and continuity.

The directions of further research include the following: preparation of the future teacher for the prevention of intolerant behavior in students of CEE; formation of tolerance in the conditions of information space, formation of educational environment and others.
References

Artimonova T. Osnovni dukhovni priorytety student-s'koyi molodi: napryamy transformatsiy / T. Artimonova // Vyshcha shkola Ukrayiny. 2008. № 1. S. 72-75

Bekh I. D. Vykhovannia osobystosti: [navch. posibnyk] / I.D.Bekh. - Kyiv.: Lybid', 2008. - $848 \mathrm{~s}$

Bekh I. D. Pochuttya tsinnosti inshoyi lyudyny yak moral'nyy priorytet osobystosti / I. D. Bekh // Pochatkova shkola. 2001. № 12.S. $32-35$

Hordieieva K. S. Profesiini tsinnosti v systemi sotsial'no-pedahohichnoi roboty: psykholohichnyi aspekt / K.S. Hordieieva // Humanizatsiia navchal'novykhovnoho protsesu: zbirnyk naukovykh prats' / [za zah. red. prof. V. I. Sypchenka].- Slov'ians'k: DDPU, 2014. - Vypusk LXVIII. - Ch. I. - S. 182-188.

Entsyklopediia osvity [entsyklopediia ] / V.H.Kremen'. - Kyiv: Yurinkom Inter, 2008. - $1040 \mathrm{~s}$.

Etyka: [navch. posibnyk] / V O.Lozovoi, M.I.Panov, O.A.Stasevs'ka ta in. K.: Yurinkom Inter, 2002. - 224 s. - S. 103

Zhelanova V.V. Teoretyko-metodolohichni aspekty problemy tsinnostey osobystosti / V.V. Zhelanova, A.V. Petsanova // Visnyk Luhans'koho natsional'noho pedahohichnoho universytetu im. T. Shevchenka (pedahohichni nauky). 2008. № 7. S. 114-119.

Zalesova H. V. Tolerantnist' yak filosofs'ke, sotsial'ne i psykholohopedahohichne ponyattya / I. V. Zalesova // Naukovyy visnyk Chernivets'koho universytetu: zb. nauk, prats'. Vyn. 747. Pedahohika ta psykholohiya. Chernivtsi: Chernivets'kyy nats. u-t, 2015. S. 53-60.

Kalashnikova L.U. Umovy formuvannia sotsial'noi pozytsii studenta / L.U.Kalashnikova // Pedahohika ta psykholohiia. 2014. Vyp. 45. S. 125-134.

Solovei M.I., Kudina V.V., Spitsyn le.S. Profesiino-pedahohichna pidhotovka maibutn'oho vchytelia v kredytno-modul'nii systemi orhanizatsii navchannia: [navchal'nyi posibnyk] / M.I.Solovei, V.V.Kudina, le.S.Spitsyn. Kyiv: Lenvit, 2013. 414 s. S.148.

Sukhomlyns'ka O. V. Tsinnosti u vykhovanni molodi ta ditey: stan rozroblennya problemy. Pedahohika i psykholohiya. 1997. № 1. S. 105-111.

Khomyakov M. B. Tolerantnost': paradoksal'naya tsennost' / M. B Khomyakov // Zhurnal sotsiologii i sotsial'noy antropologii. 2003. № 4. T. VI. № 4. S. 98-112.

Tsinnosti osvity i vykhovannia: [navch. posibnyk] / O.V.Sukhomlynska. Kyiv, 1997.

Filosofs'kyy entsyklopedychnyy slovnyk/ [holova redkol. V. I. Shynkaruk]. K.: Abrys, 2002. S. 642

Надійшла до редколегії 15.05.21

Людмила Левицька, канд. пед наук, доц

ORCID iD: 0000-0002-9955-0453

Київський національний університет імені Тараса Шевченка, Київ, Україна

\section{ТОЛЕРАНТНІСТЬ ЯК ЦІННІСТЬ МАЙБУТНЬОГО ВИКЛАДАЧА ВИЩОЇ ШКОЛИ}

Розкрито підходи до трактування терміну "толерантність" як людської чесноти, здатності мати права і свободи, не порушуючи прав і свобод інших; як доброзичливе ставлення до індивідуальних і групових відмінностей (релігійних, етнічних, культурних, цивілізаційних). Висвітлено типи та принципи толерантності, иляхи їі реалізації у вихованні через педагогіку толерантності, педагогіку співробітництва, педагогіку успіху, педагогіку діалогу, педагогіку ненасилля. Окреслено підготовку майбутнього педагога до формування толерантності як важливого компонента системи його професійної підготовки. Визначено організаційно-педагогічні умови закладу вищої освіти, що забезпечують підготовку майбутніх педагогів до формування у них толерантності: формування толерантного простору, середовища, яке характеризується єдністю всіх суб'єктів виховного процесу і форм організації їхніх відносин; культура спілкування в діалозі як взаєморозуміння, взаємоповага, співчуття і співпереживання, відчуття партнерства; синергетичне мислення, яке дозволяє сприймати широкий спектр особистісних якостей, індивідуальних і етнічних проявів людини; особистісно оріснтований підхід у виховному процесі, основою якого є суб'єкт-суб'єктні відносини у системі "вихователь-вихованець"; оптимальне поєднання теоретичного, методичного і практичного складників підготовки майбутніх педагогів до формування у них толерантності та толерантності учнів; урахування особливостей особистісно-зорієнтованого навчання в підготовці майбутніх педагогів до формування толерантності учнів; активізація пізнавальної діяльності студентів шляхом створення ситуацій; застосування інтерактивних технологій навчання.

Ключові слова: формування, толерантність, педагогічна умова. 